\title{
Yale Agrarian Studies Series James C. Scott, Series Editor
}

The Agrarian Studies Series at Yale University Press seeks to publish outstanding and original interdisciplinary work on agriculture and rural society - for any period, in any location. Works of daring that question existing paradigms and fill abstract categories with the lived experience of rural people are especially encouraged.

-James c. scott, Series Editor

James C. Scott, Seeing Like a State: How Certain Schemes to Improve the Human Condition Have Failed

Steve Striffler, Chicken: The Dangerous Transformation of America's Favorite Food

Alissa Hamilton, Squeezed: What You Don't Know About Orange fuice James C. Scott, The Art of Not Being Governed: An Anarchist History of Upland Southeast Asia

Sara M. Gregg, Managing the Mountains: Land Use Planning, the New Deal, and the Creation of a Federal Landscape in Appalachia

Michael R. Dove, The Banana Tree at the Gate: A History of Marginal Peoples and Global Markets in Borneo

Edwin C. Hagenstein, Sara M. Gregg, and Brian Donahue, eds., American Georgics: Writings on Farming, Culture, and the Land

Timothy Pachirat, Every Twelve Seconds: Industrialized Slaughter and the Politics of Sight

Andrew Sluyter, Black Ranching Frontiers: African Cattle Herders of the Atlantic World, I500-I900 
Brian Gareau, From Precaution to Profit: Contemporary Challenges to

Environmental Protection in the Montreal Protocol

Kuntala Lahiri-Dutt and Gopa Samanta, Dancing with the River: People and Life on the Chars of South Asia

Alon Tal, All the Trees of the Forest: Israel's Woodlands from the Bible to the Present

Felix Wemheuer, Famine Politics in Maoist China and the Soviet Union Jenny Leigh Smith, Works in Progress: Plans and Realities on Soviet Farms, $1930-1963$

Graeme Auld, Constructing Private Governance: The Rise and Evolution of Forest, Coffee, and Fisheries Certification

Jess Gilbert, Planning Democracy: Agrarian Intellectuals and the Intended New Deal

Jessica Barnes and Michael R. Dove, eds., Climate Cultures: Anthropological Perspectives on Climate Change

Shafqat Hussain, Remoteness and Modernity: Transformation and Continuity in Northern Pakistan

Edward Dallam Melillo, Strangers on Familiar Soil: Rediscovering the ChileCalifornia Connection

Devra I. Jarvis, Toby Hodgkin, Anthony H. D. Brown, John Tuxill, Isabel López Noriega, Melinda Smale, and Bhuwon Sthapit, Crop Genetic Diversity in the Field and on the Farm: Principles and Applications in Research Practices

Nancy J. Jacobs, Birders of Africa: History of a Network

Catherine A. Corson, Corridors of Power: The Politics of U.S. Environmental Aid to Madagascar

Kathryn M. de Luna, Collecting Food, Cultivating People: Subsistence and

Society in Central Africa Through the Seventeenth Century

Carl Death, The Green State in Africa

James C. Scott, Against the Grain: A Deep History of the Earliest States

For a complete list of titles in the Yale Agrarian Studies Series, visit yalebooks .com/agrarian. 
This page intentionally left blank 
Against the Grain 
This page intentionally left blank 